\title{
БАГАТОФУНКЦІОНАЛЬНИЙ СТИМУЛЯТОР БІОЛОГІЧНО АКТИВНИХ ТОЧОК
}

\author{
Богомолов М.Ф. доцент, к.Т.н. \\ nbogom@yahoo.com \\ орець $\boldsymbol{C} . \boldsymbol{A}$. ,студентка \\ orets02@gmail.com \\ Факультет біомедичної інженерії \\ Національний технічний університет України \\ “Київський політехнічний інститут імені Ігоря Сікорського” \\ м. Київ, Україна
}

\begin{abstract}
Реферат - Поєднання трьох окремих методів пунктури , а саме: електричної, лазерної та ультразвукової та пристрою пошуку біологічно активних точок за електропровідністю шкіри допоможе пришвидшити встановлення лікарем більш точного клінічного і пунктурного діагнозу пацієнту неінвазивним способом. Реалізація лікувального ефекту здійснюється за рахунок пунктурного ефектуточка акупунктури- канал (меридіан)- орган. Можливість комбінування різних методів впливу також може полегшити роботу лікаря та більш ефективніше діяти на БАТ не викликаючи звикання до однотипного подразнення.

Ключові слова - БАТ, акупунктура, фонопунктура, напівпровідниковий лазер, лазеропунктура, опір, електропунктура, ультразвук.
\end{abstract}

\section{I. ВСТУП}

В наш час в умовах різних епідемій, екологічної ситуації зростає необхідність швидкої діагностики найменших відхилень стану організму від норми . В цьому можуть допомогти будь-які додаткові способи виявлення порушень. Недоліки медикаментозної терапії загострюють інтерес до немедикаментозних методів лікування, i в першу чергу-до різних методів фізіотерапії, серед яких не останнє місце займає рефлексотерапія. Одним 3 новітніх напрямків рефлексотерапії $\epsilon$ розвиток методів пунктурної фізіотерапії.

Широке розповсюдження отримав метод вимірювання опору біологічно активних точок- електропунктурна діагностика (ЕД). Біологічно активні точки (БАТ)-зони (точки) поверхні тіла, що $\epsilon$ проекцією нервових закінчень відповідних тканин i органів [1]. Найперспективнішими є методи пунктурної фізіотерапії, в основі яких лежить вплив на точки акупунктури електричним струмом, лазерним випромінюванням та ультразвуком. Їх перевагами є: мінімум протипоказань, неінвазивне проведення лікувальних процедур, відсутність алергічних реакцій і побічних явищ, що роблять ці методи фізіотерапії вельми привабливим для лікування, профілактики і реабілітації.
На даний час перспективним є застосування електропунктурної діагностики для встановлення причини виникнення хвороб , наприклад, плеврального випоту [2]. Поширеним, також, стає застосування лазеропунктури, наприклад, у профілактиці ускладнень протипухлинного лікування в онкоурологічних хворих. Показано, що під впливом випромінювання лазера на БАТ, відбувається стимуляція компенсаторнопристосувальних процесів в організмі онкологічного хворого, що супроводжується формуванням благоприємної для організму неспецифічної антистресової адаптаційної реакції активації неспецифічного захисту. Це приводить до значного зниження різних ускладнень, попереджує розвиток стійкої лейкопенії i вираження інтоксикації при стандартному хіміо-променевому лікуванні, а також підвищує резистентність до інших агресивних дій в процесі специфічного протипухлинного лікування [3].

Стаття присвячена розробці неінвазивного комбінованого оптоакустоелектронного біомедичного стимулятору БАТ людини 3 застосуванням методів електро-, лазеро- та ультразвукової пунктури, як комплексно, так i окремо.

На даний момент існує багато приладів для проведення лікувального впливу на БАТ, але аналогів нашої розробки не було виявлено. 
Актуальністю даного приладу $є$ комбінування методів впливу на біологічно активні точки та можливість провести процедуру знаходження БАТ не змінюючи положення тіла пацієнту та не змінюючи приладу для подальшої процедури стимуляції.

\section{II. МЕТА ДОСЛІДЖЕНЬ}

Мета роботи: розробка терапевтичного апарату для стимуляції біологічно активних точок , який об'єднує в собі три методи пунктури, сприяе детектуванню порушення гомеостазу на ранніх етапах захворювання різних систем організму та проведенню лікувальних процедур одразу після виявлення відхилень, підбираючи найбільш ефективний метод впливу на БАТ.

\section{III. МАТЕРІАЛИ ТА ТЕХНІЧНІ ХАРАКТЕРИСТИКИ МЕТОДІВ СТИМУЛЯЦЇ̈ БАТ}

Біологічно активні точки (БАТ) - морфофункціонально відособлені ділянки, розташовані в підшкірній жировій клітковині, що містять рихлу з'єднувальну тканину, багату на огрядні клітини, і тісно пов'язані 3 належними нервовими провідниками. У $42 \%$ випадків у ділянці пунктурних точок виявляється підшкірний нерв, в 40\% підшкірна вена, а в 10\% - підшкірна артерія 3 периваскулярними нервовими сплетіннями. Точки впливу характеризуються максимальною концентрацією нервових елементів і скупченням огрядних клітин, що містять найважливіші біологічні регулятори. Також вони мають підвищену больову чутливість, особливо до натиску, вищу шкірну температуру, посилене поглинання кисню, високий рівень обмінних процесів, змінний електрошкірний опір [4].

БАТ (рис.1) являє собою пору в шкірі (5), на дні якої розташовуються нервові закінчення (6). Від нервових закінчень відходять нервові волокна до центральної нервової системи (ЦНС). Між нервовими закінченнями і верхнім шаром шкіри, який складається із стовбурових клітин (1) 3 підвищеною провідністю, на відстані 100-200 мкм від верхнього шару знаходиться колаген (3) 3 діелектричною проникністю $\varepsilon_{\mathrm{r}}<10$. У верхньому шарі $є$ вікно діаметром $\mathrm{d} \approx 0,1-0,3$ MM [5].

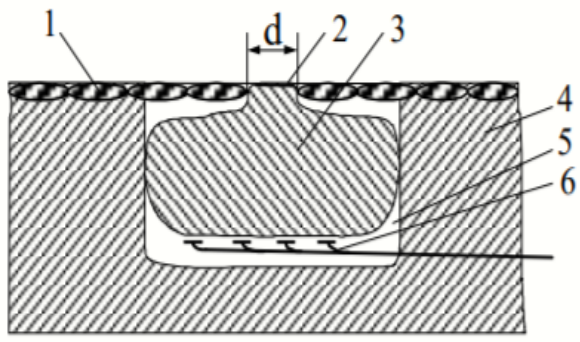

Рис. 1. Біологічна (просторова) модель БАТ: 1 - огрядні клітини; 2 - вікно; 3 - колаген; 4 - шкіра; 5 - пора в шкірі; 6 - нервові закінчення

Біологічна модель БАТ: область між шкірою і нервовим волокном нагадує форму циліндра 3 розмазаними межами бічних стінок. Діаметр БАТ в спокійному стані не більше 1 мм, а в збудженому - до декількох міліметрів [5].

Електричний опір шкіри менший у ділянці відповідної локалізації точок акупунктури в порівнянні 3 навколишніми ділянками, що дозволяє провести їх топічну діагностику і дає мотив стверджувати про вибірковий вплив рефлексотерапевтичних чинників. В акупунктурних точках виражені значно сильніше і п'єзоелектричні властивості, що дозволяють генерувати або модулювати нервовий імпульс навіть за низької напруженості ультразвуку. Зони локалізації точок різняться також оптичними властивостями, що обгрунтовує використання світлотерапії на БАТ (лазерне та ультрафіолетове випромінювання) [4].

Для того, щоб розпочати лікувальну стимуляцію точки акупунктури потрібно провести їі пошук. Електричний опір біологічно активних точок складає приблизно 800 кОм на площі 2 мм $^{2}$ [4]. В основу для реалізації функції пошуку було взято електричну принципову схему, що наведена в роботі [6].

Для проведення пошуку використовують електроди, що мають бути виконані з металу високої електропровідності (мідні електроди), причому обидва електроди мають бути жорстко закріплені на корпусі. Цим зменшується відстань між робочими електродами до 7-9 мм, що виключає небажаний вплив електричного струму на організм людини. У розімкненому стані, напруга на них становить 12 В [7]. Одночасно 3 аналоговою індикацією використовуються звукові та світлові сигнали. По світлодіодному індикатору можна побачити, що чим ближче електроди до шуканої точки, тим більше частота світлових імпульсів індикатора БАТ (акупунктурна точка). 
В режимі пошуку i в режимі електростимуляції генератор виробляє імпульси пікової форми мінливої амплітуди і частоти . Частота генератора змінюється в межах 1-100 Гц.

Струм споживаний в режимі пошуку "10-15 мА (максимальний), в режимі" впливу "5 мА (Мінімальний). Широкий діапазон напруги живлення 3-9 В. Тривалість активної фази лікувального імпульсу дорівнює в середньому 70-120 мкс [6].

Електропунктура - один 3 різновидів рефлексотерапії, при якій впливають електричним струмом на область точок акупунктури. 3 цією метою на область (зону) точки акупунктури накладають електроди i пропускають через них електричний струм. Електричний струм вважається найбільш адекватним подразником для точок акупунктури, які відрізняються рядом електрофізіологічних особливостей.

Для стимуляції акупунктурних точок проводять вплив катодом (негативним полюсом), а досягається накладенням на точки акупунктури анода. Також значення струму залежить від локалізації та глибини положення точки [8].

В частину приладу, що відповідає за електростимуляцію входить: блок живлення, генератор імпульсів та підсилювач, звідки сигнал подається на електроди, які далі взаємодіють 3 БАТ. Апарат використовує генератор імпульсів, що змінюються короткотривалим, високочастотним імпульсом, необхідним для зменшення звикання БАТ до тривалої стимуляції. Зміна параметрів (частоти, амплітуди) приладу проводяться за рекомендацією лікаря.

Вплив на організм 3 лікувальною або профілактичною метою низькоенергетичним лазерним випромінюванням на БАТ отримало назву пунктурної лазеротерапії, або лазеропунктури. Лазеропунктура, в протиставленні голкотерапії, найбільш прогресивна і прийнятна.

Дані клінічних спостережень і експериментальних д досліджень $[9,10,11]$ свідчать про більш високу ефективність комплексної лазеротерапії в тих випадках, коли до базових принципів лікування, які передбачають безпосередній вплив на вогнище ураження, додають лазеростимуляцію точок акупунктури або рефлексогенних зон.

Виділяють два основні способи лазерної рефлексотерапії: лазеропунктура - дія лазерним випромінюванням на точки акупунктури без порушення цілісності шкірних покривів та лазероакупунктура - глибока лазерна стимуляція БАТ через порожнисту голку, в яку вводиться світлопровід, який проводить лазерне випромінювання.

Проведення лазеропунктурної стимуляції БАТ відбувається 3 застосуванням низькоінтенсивного , напівпровідникового лазеру монохроматичного червоного світла. Напівпровідникові лазери - найбільш споживаний в побуті вид лазерів, тому для того щоб зменшити габарити лазера ми вирішили використовувати саме цей вид. Окрім цього напівпровідникові лазери також застосовуються в спектроскопії, в системах накачування інших лазерів, а також в медицині [12].

Ми обрали одномодовий одночастотний гелій-неоновий лазер типу ЛГН-207А, 3 довжиною хвилі 0,6328 мкм, потужністю випромінювання 1,5 мВт та діаметром пучка лазерного випромінювання 1,4 мм. Важливим рішенням для зменшення витрат лазерного опромінювання стало використання контактного світловоду.

$$
\text { У приладі використовується }
$$

напівпровідниковий лазер, який випромінює світло, пучок якого збирається у конденсорі для того, аби розсіювання було меншим. Промінь червоного світла оптичного діапазону спрямовується на біологічний об'єкт в нашому випадку на БАТ та проводить відповідний вплив та стимулюючий ефект на неї.

Підставою для розробки фонопунктури послужило те, що ультразвук може надавати контрольоване роздратування периферичного рефлекторного елемента, а 3 іншого боку, викликає зміну електричних характеристик тканини в БАТ, що $є$ біофізичною основою терапевтичної дії фонопунктури.

Відомо, що пристрій для ультразвукової пунктури (фонопунктури), заснований на тому, що ультразвук надає механічний i тепловий вплив. Деформуючи клітини, він сприяє утворенню деформацій, тепла i різниці потенціалів в акупунктурних точках, що в кінцевому підсумку призводить до лікувального ефекту [13]. В основі дії ультразвуку лежить 
мікромасаж тканин, який викликає нагрів біологічно активних точок, обумовлюючи виникнення рефлексу.

Як відомо [4] точки акупунктури багаті сполучною тканиною, нервовими стовбурами, венами, рецепторами, ефекторами. В акустичному плані тканини в точках акупунктури аналогічні до м'язових тканин. Площа точки коливається від 0,4 до $10 \mathrm{~mm}^{2}$. Глибина розташування від 3 до 25 мм. При фонопунктурі використовуються інтенсивності ультразвуку не вище 0,2 Вт / см$^{2}$. За даними Американського інституту по застосуванню ультразвуку в медицині ультразвукове опромінення практично не має шкідливої біологічної дії на тканини при інтенсивності нижче 0,2 Вт / $\mathrm{cm}^{2}[14,15]$.

Ультразвукова пунктура проводиться 3 використанням впливу ультразвукової імпульсної дії низької частоти та частоти релаксації 40 і 31 кГц, 3 використанням стрижневого випромінювач півхвильового пакетного типу з п'єзокераміки - ЦТБС-3, що задовольняє умови випромінювання [14] .

При проведені стимуляції БАТ використовуємо такі енергетичні параметри : при слабкому ступені стимуляції ультразвуковий вплив відповідає інтенсивності 2-3 мкм, при тривалості експозиції 5-20 с на одну точку, частота модуляції 1-10 Гц; при середньому- інтенсивність ультразвуку 3-4 мкм, 3 впливом 20-30 с на одну точку, частота модуляції 18 і 37 Гц; при сильному ступені стимуляції- відповідно 4-5 мкм і 30-60 с на одну точку, частота модуляції 75 Гц. При проведені стимуляції БАТ густина інтенсивності ультразвукових коливань не повинна перевищувати 1 Вт $/ \mathrm{cm}^{2}$, а найкраще повинна бути в межах від 0,05-0,7 Вт /см² [16].

\section{IV. ФУНКЦІОНАЛЬНА СХЕМА ПРИЛАДУ}

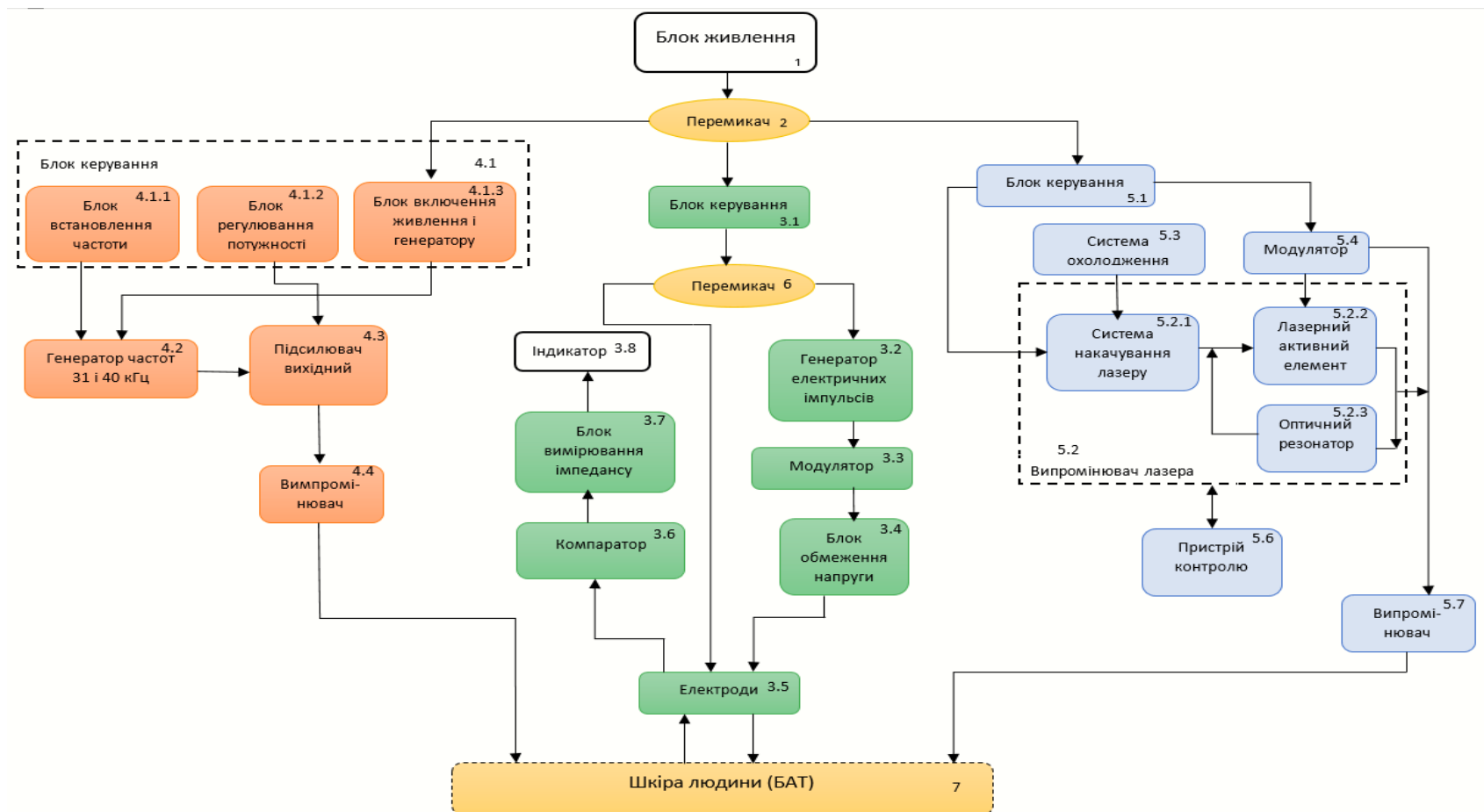

Рис.2.Функціональна схема поліфункціонального апарату для стимуляції БАТ

Для розуміння принципів дії нашого приладу, навели функціональну блок-схему.

Функціональна схема умовно (кольорами) поділена на 3 частини. Ці частини описують різні типи стимуляції біологічно активних точок. Зеленим кольором позначено частину схеми, що відповідає за пошук та електропунктуру; синій колір- це лазеропунктура; помаранчевий- фонопуктура.
Принцип роботи схеми: 3 блока живлення (1) поступає сигнал на один із трьох блоків керування $(3.1 ; 4.1 ; 5.1)$, вибір якого здійснюється перемикачем (2). При виборі блоку керування (3.1) перемикачем (6) обираємо електропунктурну стимуляцію чи пошук БАТ.

При детекції БАТ показники з електродів (3.5) поступають на компаратор (3.6), потім на блок вимірювання імпедансу (3.7), а далі на індикатор (цифровий чи стрілковий) для 
визначення наявності запальних чи деструктивних процесів.

При виборі електростимуляції перемикачем (6) починають генеруватися імпульси блоком (3.2). Використовуються поперечні електромагнітні хвилі малої потужності, далі вони поступають на модулятор (3.3), блок обмеження напруги (3.4) i подаються на електроди (3.5), за допомогою яких проводять процедуру.

Частина схеми, що зображена помаранчевими блоками, відповідає за частину приладу, що призначена для ультразвукового стимулювання БАТ. Вона містить послідовно 3'єднані генератор частоти (4.2) 31 і 40 кГц, підсилювач вихідний (4.3), випромінювач (4.4), а також містить блок керування (4.1). Блок керування (4.1) містить блок установки частоти (4.1.1), вихід якого з'єднаний з генератором (4.2), блок регулювання потужності (4.1.2), вихід якого з'єднаний 3 підсилювачем потужності (4.3), блок включення живлення та генератора (4.1.3), вихід якого 3'єднаний 3 блоками (4.2).

Робота фонопуктурної частини апарату здійснюється наступним чином. 3 блоку керування (4.1) проводиться включення живлення генератора (4.2) і підсилювача вихідного (4.3). Блоком установки частоти (4.1.1) встановлюється частота релаксації тканин точки акупунктури. За командою блоку (4.1.3) включається генератор (4.2) випромінює повздовжні акустичні хвилі 3 малою амплітудою, але 3 надвисоким прискоренням $9 \cdot 10^{7} \mathrm{~cm} / \mathrm{c}^{2}$. Електричні коливання посилюються в вихідному підсилювачі (4.3). Вони збуджують випромінювач (4.4) 3 концентраторами. Кінець концентратора підноситься до акупунктурної точки і збуджує її протягом заданого часу.

При проведені лазеропунктури перемикачем (2) обираємо блок керування (5.1) 3 нього впливаємо за допомогою електромагнітного поля на випромінювач лазера (5.2). Потім за допомогою оптичного резонатору (5.2.3), що виконує позитивний зворотній зв'язок, та блоків (5.2.1) та (5.2.2) утворюється лазерне монохроматичне випромінювання, що використовується для впливу на БАТ за допомогою випромінювача (5.7). Параметри ланки позитивного зворотного зв'язку вибираються так, щоб енергія випромінювання, яка передається з виходу лазерного підсилювача на його вхід, була достатньою для компенсації втрат в замкнутому ланцюзі зворотного зв'язку.

\section{V. ВИСНОВКИ}

1. При створенні функціональної схеми приладу були опрацьовані існуючі прилади для пошуку та електростимуляції БАТ та пристрій для фонопунктури. Також були опрацьовані праці дослідників, що пов'язані з використанням методів пунктурної стимуляції у лікуванні різних захворювань . Було враховано їх переваги при створені схеми власного пристрою.

2. Наукова новизна розробки полягає у використанні універсальних технологій для терапевтичної дії на БАТ під впливом різних джерел випромінювання . Розроблений прилад не має аналогів. За допомогою цього приладу відбувається: багатофункціональне обстеження людини, проведення профілактичних заходів, терапевтичне корегування патологічних проявів хвороби.

3. Комбінування методів стимуляції також $\epsilon$ корисним при курсі лікування всього організму, коли потрібно діяти на БАТ в різних частинах тіла. Наприклад , якщо потрібна стимуляція БАТ, що розташовані на голові, то ультразвуковий вплив не бажаний, тому для їх стимуляції доцільно використовувати лазер, що присутній в нашому приладі . Поєднання саме цих функцій роблять апарат високопрактичним і конкурентно спроможним в нетрадиційних методах лікування.

\section{ПЕРЕЛІК ПОСИЛАНЬ}

1. Полякова Е. Альтернативна медицина: Міфи i реальність / Олена Полякова//.-СПб. : ЗАТ “Торгово-видавничий дім " Амфора ", 2015.-62 с.

2. ОПанасенко Н. С. ПЕРСПЕКТИВЫ ПРИМЕНЕНИЯ ЭЛЕКТРОПУНКТУРНОЙ ДИАГНОСТИКИ ДЛ УСТАНОВЛЕНИЯ ЭТИОЛОГИИ ПЛЕВРАЛЬНЫХ ВЫПОТОВ [Електронний ресурс] / Н. С. Опанасенко // Український пульмонологічний журнал. 2008, № 1. - 2008. - Режим доступу до ресурсу: http://www.ifp.kiev.ua/doc/journals/upj/08/pdf081/26.pdf.

3. ПРОФИЛАКТИКА ПРОТИВООПУХОЛЕВОГО ОСЛОЖНЕНИЙ ОНКОУРОЛОГИЧЕСКИХ БОЛЬНЫХ С ИСПОЛЬЗОВАНИЕМ ЛАЗЕРНЫХ ТЕХНОЛОГИЙ [Електронний ресурс] / [Е. А. Шейко, А. И. Шихлярова, А. Н. Шевченко та ін.]. - 2014. - Режим доступу до ресурсу: https:/www.appliedresearch.ru/ru/article/view?id=6124.

4. Акупунктура [Електронний ресурс] - Режим доступу до ресурсу: http://kaf-fis-reab.dsmu.edu.ua/wpcontent/uploads/2015/02/\%D0\%A72\%D0\%A08.pdf.

5. Мичковський Ю. Г. РАДІОЕЛЕКТРОНІКА БІОЛОГИЧНО АКТИВНИХ ТОЧОК [Електронний ресурс] / Ю. Г. Мичковський // Вісник КрНУ імені Михайла 
Остроградського. Випуск 4/2012 (75). - 2012. - Режим доступу до ресурсу: http://www.kdu.edu.ua/statti/2012-4-1(75)/45.pdf.

6. Соболь О. М. Пристрій для пошуку та діяння на біологічно активні точки [Електронний ресурс] / О. М. Соболь, С. Г. Зобов. - 1994. - Режим доступу до ресурсу: http://uapatents.com/2-5487-pristriji-dlya-poshuku-ta-diyannya-nabiologichno-aktivni-tochki.html.

7. Самохин А.В.Элетропунктурная диагностика и терапия по методу Р. Фолля [Електронний ресурс] / Самохин А.В., Готовский Ю.В. //"ИМЕДИС",2006. - 528 с. -Режим доступу до ресурсу: https://www.booksmed.com/luchevayadiagnostika/2253-yeletropunkturnaya-diagnostika-i-terapiya-pometodu-follya-samoxin.html

8. Сукиасян А. А. СОВРЕМЕННЫЕ ТЕХНОЛОГИИ В МИРОВОМ НАУЧНОМ ПРОСТРАНСТВЕ / А. А. Сукиасян. Уфа: ООО “ОМЕГА САЙНС”, 2019. - 2

9. Жаркин Н. А. ВЛАГАЛИЩНАЯ ЛАЗЕРОПУНКТУРА [Електронний ресурс] / Н. А. Жаркин. - 2014. - Режим доступу до ресурсу: http://www.natural-sciences.ru/pdf/2004/11/11.pdf.

10. Полякова А. Г. КВЧ- И ЛАЗЕРОПУНКТУРА В КОМПЛЕКСНОЙ МЕДИЦИНСКОЙ РЕАБИЛИТАЦИИ ПАЦИЕНТОВ С ПАТОЛОГИЕЙ СУСТАВОВ И ПОЗВОНОЧНИКА : автореф. дис. на здобуття наук. ступеня докт. мед. наук : спец. 14.00.51 "восстановительная медицина, лечебная физкультура и спортивная медицина, курортология и физиотерапия" / Полякова А. Г. - Москва, 2004. - 48 с.
11. Бальнео-, лазеротерапия, акуи лазеропунктура в коррекции инфертильности у больных хроническим простатитом [Електронний ресурс] / А. Т.Терешин, Н. Г. Истошин, В. А. Путилин, В. В. Машнин. - 2009. - Режим доступу до ресурсу: https://cyberleninka.ru/article/n/balneo-lazeroterapiyaakui-lazeropunktura-v-korrektsii-infertilnosti-u-bolnyh-

hronicheskim-prostatitom/viewer.

12. КЛИМКОВ Ю. М. ЛАЗЕРНАЯ ТЕХНИКА [Електронний ресурс] / Ю. М. КЛИМКОВ, М. В. ХОРОШЕВ // МИИГАиК. - 2014. - Режим доступу до ресурсу: http://www.miigaik.ru/upload/iblock/5ee/5ee70d02887034adc11e67 cee286392c.pdf.

13. А.А.Чіркін. Метаболічні реакції організму на різні варіанти ультразвукового впливу. Автореферат дисертації на здобуття наукового ступеня доктора медичних наук. - Мн .: 1976, 34 с; Л.Р.Гаврілов, Е.М.Цірульнікова. Сфокусований ультразвук в фізіології і медицині. - Л .: Наука, 1980, 179 с

14. Биленко Б. С. Устройство для фонопунктуры [Електронний ресурс] / Б. С. Биленко, Т. Г. Тышкевич, Л. Е. Шейнман - Режим доступу до ресурсу: https://findpatent.ru/patent/216/2160081.html.

15. Ф.Г.Портнов. Електропунктаціонная рефлексотерапія. - Рига: Наука, 1980, 218 с.

16. Рефлексотерапия в курортологии - Ультразвуковая пунктура [Електронний ресурс] - Режим доступу до ресурсу: https://lmed.in/info/literatura/refleksoterapiya-v-kurortologii25.html. 


\title{
МНОГОФУНКЦИОНАЛЬНЫЙ СТИМУЛЯТОР БИОЛОГИЧЕСКИ АКТИВНЫХ ТОЧЕК
}

Богомолов М.Ф. доцент, к.т.н. nbogom@yahoo.com

Орец $\boldsymbol{E} . \boldsymbol{A}$. студентка

orets02@gmail.com

Факультет биомедицинской инженерии Национальный технический университет Украины “Киевский политехнический институт имени Игоря Сикорского”

Реферат - Сочетание трех отдельный методов пунктуры, а именно: электрической, лазерной и ультразвуковой и устройства поиска биологически активных точек за электропроводимостью кожи поможет ускорить установление врачом более точного клинического и пунктурного диагноза пациента неинвазивным способом. Реализачия лечебного эффекта осуществляется за счет пунктурного эффекта -точка акупунктуры- канал (меридиан) - орган. Возможность комбинирования разных методов влияния тоже может облегчить работу врача и более эффективнее действовать на БАТ не вызывая привыкание к однотипному раздражению. Ключевые слова: БАТ, акупунктура, фонопунктура, полупроводниковый лазер, лазеропунктура, поиск точки, электропунктура, ультразвук.

\section{UDC 615.81}

\section{MULTI-FUNCTIONAL STIMULANT OF BIOLOGICALLY ACTIVE POINTS}

Bogomolov M., Associate Professor, Ph.D. nbogom@yahoo.com

Orets $\boldsymbol{E}$., student orets02@gmail.com

Faculty of Biomedical Engineering National Technical University of Ukraine "Igor Sikorsky Kyiv Polytechnic Institute"

Kiev, Ukraine

\begin{abstract}
The combination of three separate puncture methods, namely electric, laser and ultrasound, and a device for finding biologically active points by the electrical conductivity of the skin will help speed up the setting of a more accurate clinical and puncture diagnosis of the patient by the doctor in a non-invasive way. The implementation of the treatment is carried out by puncturing: acupuncture point - channel (meridian) organ. The possibility of combining different methods of exposure can also facilitate the doctor's work and more effectively influence BAP without causing addiction to the same type of irritation.
\end{abstract}

Key words: BAP, acupuncture, phonopuncture, semiconductor laser, laser puncture, point search, electropuncture, ultrasound. 